\title{
Computed tomography based estimates of regional gas and tissue volume of the lung in supine subjects with chronic airflow limitation or fibrosing alveolitis
}

\author{
A B MILlAR, B FROMSON, B A STRICKLAND, D M DENISON \\ From the Lung Function and Computed Tomography Unit, Brompton Hospital, London
}

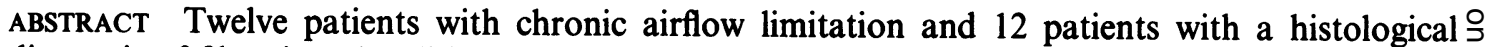
diagnosis of fibrosing alveolitis were studied. The calculated mean (SD) tissue volume of a single $\vec{\nabla}$ lung at total lung capacity was $467(91) \mathrm{ml}$ in the patients with alveolitis, which was $43 \%(14 \%)$ more than predicted for healthy people of the same age, sex, and height. The tissue volume of a $\frac{\Phi}{7}$ single lung at total lung capacity was $436(82) \mathrm{ml}$ in the patients with chronic airflow limitation, $\frac{\mathcal{D}}{\mathbb{Q}}$ which was $26 \%(21 \%)$ more than predicted. At residual volumes the tissue contents of the fibrotic and the obstructed lungs changed very little (to 407 (84) $\mathrm{ml}$ and 433 (84) $\mathrm{ml}$ respectively). This allowed tissue volume to be used as a marker of position within the lung, to match inspiratory and expiratory slices and to calculate regional ventilation. In both groups local ventilation was diminished and more variable than in healthy lungs - that is, in the mid $70 \%$ of lung volume the local residual volume to total gas volume ratios (RV/TGV) were $32 \%(10 \%)$ in the fibrotic group and $66 \%(14 \%)$ in the group with chronic airflow limitation, compared with $23 \%(5 \%)$ in healthy $\frac{\circ}{\Phi}$ subjects. As expected, the fibrotic lungs were much denser $(0.246(0.036) \mathrm{g} / \mathrm{ml})$ and the lungs with $\stackrel{\varrho}{\Rightarrow}$ chronic airflow obstruction were less dense $(0.114(0.026) \mathrm{g} / \mathrm{ml})$ than were healthy lungs $\left(0 \cdot 126 \frac{3}{3}\right.$ $(0.017) \mathrm{g} / \mathrm{ml})$.
\end{abstract}

We have previously shown that computed tomography could measure the total gas and tissue volumes and the regional vital capacities and residual volumes of the lungs in healthy men. ${ }^{1}$ The aim of the present study was to discover how well computed tomography could recover the same volumes in patients with lung disease.

\section{Methods}

We studied 12 patients with chronic airflow limitation and 12 patients with fibrosing alveolitis. They were chosen from larger groups of patients with probable emphysema or fibrosis in whom computed tomography had been performed for clinical reasons. Their scans, which were stored on magnetic tape, were selected for more detailed study retrospectively, on the basis of clinical, radiographic, functional, and (in the case of fibrosing alveolitis) histological confirmation of the diagnosis.

Address for reprint requests: Professor DM Denison, Brompton Hospital, London SW3 6HP.

Accepted 22 July 1986
The 12 patients with chronic airflow limitation were all referred for assessment of emphysema or for evaluation of bullous lung disease that was shown to be generalised emphysema. ${ }^{2}$ All 12 had presented $\frac{}{3}$ with complaints of breathlessness and poor exercise tolerance; three had $\alpha_{1}$ antitrypsin deficiency. All 약 admitted to cough and sputum production on direct questioning, and had chronic bronchitis, as defined by the Medical Research Council criteria. ${ }^{3}$ Anthro- $\frac{D}{0}$ pometric, functional, and clinical data on these patients are given in tables 1 and 2 . On the basis of $\stackrel{N}{\sigma}$ this evidence and the radiological details of their com- $N$ puted tomography scans we concluded that these $N$ patients had chronic bronchitis and emphysema. This point is examined further below.

Each patient was asked to breathe in to total lung capacity, signal and hold that position for five seconds while an inspiratory scan was taken. They were also asked to breathe out to residual volume, signal ${ }^{\circ}$ and hold that position while an expiratory scan was $\overparen{\mathbb{D}}$ taken. Their lungs were studied in this fashion from $\frac{\rho}{\odot}$ apex to base at constant intervals of between $10-15 \frac{0}{\mathrm{~mm}}$
.

The scans were examined on a display console, with 
Table 1 Details and lung function of 12 patients with chronic airflow limitation

\begin{tabular}{|c|c|c|c|c|c|c|c|c|c|}
\hline \multirow{2}{*}{$\begin{array}{l}\text { Subject } \\
\text { No (sex) }\end{array}$} & \multirow{2}{*}{$\begin{array}{l}\text { Age } \\
(y)\end{array}$} & \multirow{2}{*}{$\begin{array}{l}\text { Height } \\
(\mathrm{cm})\end{array}$} & \multicolumn{6}{|c|}{ Lung function ( $\%$ predicted) } & \multirow{2}{*}{$\begin{array}{l}\text { Duration of } \\
\text { symptoms }(y)\end{array}$} \\
\hline & & & $F E V_{1}$ & $F V C$ & $T L C$ & $R V$ & $T L C O$ & $\mathrm{KCO}$ & \\
\hline $\begin{aligned} 1 & (\mathrm{M}) \\
2 & (\mathrm{M}) \\
3 & (\mathrm{~F}) \\
4 & (\mathrm{M}) \\
5 & (\mathrm{M}) \\
6 & (\mathrm{M}) \\
7 & (\mathrm{M}) \\
8 & (\mathrm{~F}) \\
9 & (\mathrm{M}) \\
10 & (\mathrm{M}) \\
11 & (\mathrm{M}) \\
12 & (\mathrm{~F})\end{aligned}$ & $\begin{array}{l}35 \\
43 \\
43 \\
53 \\
54 \\
56 \\
62 \\
68 \\
70 \\
70 \\
71 \\
75\end{array}$ & $\begin{array}{l}179 \\
170 \\
161 \\
177 \\
184 \\
187 \\
196^{*} \\
165 \\
166 \\
178 \\
168 \\
163\end{array}$ & $\begin{array}{r}17 \\
104 \\
26 \\
24 \\
36 \\
33 \\
26 \\
26 \\
26 \\
36 \\
26 \\
25\end{array}$ & $\begin{array}{r}35 \\
136 \\
92 \\
57 \\
70 \\
55 \\
73 \\
69 \\
75 \\
92 \\
56 \\
40\end{array}$ & $\begin{array}{l}121 \\
133 \\
149 \\
119 \\
141 \\
114 \\
127 \\
122 \\
141 \\
123 \\
120 \\
134\end{array}$ & $\begin{array}{l}327 \\
132 \\
265 \\
243 \\
269 \\
186 \\
122 \\
222 \\
243 \\
178 \\
193 \\
259\end{array}$ & $\begin{array}{l}44 \\
55 \\
23 \\
28 \\
61 \\
29 \\
28 \\
28 \\
31 \\
45 \\
40 \\
36\end{array}$ & $\begin{array}{l}78 \\
58 \\
25 \\
51 \\
83 \\
44 \\
37 \\
38 \\
43 \\
51 \\
73 \\
50\end{array}$ & $\begin{array}{r}5 \\
5 \\
7 \\
8 \\
7 \\
6 \\
10 \\
5 \\
6 \\
7 \\
6 \\
5\end{array}$ \\
\hline $\begin{array}{l}\text { Mean } \\
\text { SD }\end{array}$ & $\begin{array}{l}58 \\
13\end{array}$ & $\begin{array}{r}173 \\
10\end{array}$ & $\begin{array}{l}34 \\
23\end{array}$ & $\begin{array}{l}71 \\
27\end{array}$ & $\begin{array}{r}129 \\
11\end{array}$ & $\begin{array}{r}220 \\
60\end{array}$ & $\begin{array}{l}37 \\
12\end{array}$ & $\begin{array}{l}53 \\
18\end{array}$ & $\begin{array}{l}6 \\
2\end{array}$ \\
\hline
\end{tabular}

*Span.

FVC-forced vital capacity; TLC—-total lung capacity; RV—residual volume; TLco-transfer factor; Kco-transfer coefficient.

an organ identification subroutine that outlines the boundary of any contiguous region having radiographic densities within a nominated range. We chosethe lower density limit of -999 Hounsfield units, which excludes any tissue volume element (of $1 \times 1$ $\times 10$ to $15 \mathrm{~mm}$ ) containing more than $99.9 \%$ air. The upper density limit was -300 Hounsfield units, which excludes any volume element containing more than $70.3 \%$ of soft tissue as opposed to air (soft tissues other than fat generally have radiographic densities close to +40 Hounsfield units). This boundary outlines the pleural surface of the lung, allowing for the partial volume effect at its curved surfaces; but it also excludes large vessels radiating from the hilum for variable distance into the lung. Direct measurements of the diameters of included and excluded vessels, made with a pair of screen cursors, showed that the boundary excludes any blood vessels with diameters above $5 \mathrm{~mm}$.

Once the outlines had been obtained in this way, they were adjusted manually to include any pathological air spaces within the lung that had been excluded by the $-999 \mathrm{HU}$ limit, and to include any subpleural fibrosis that had been excluded by the $-300 \mathrm{HU}$ limit. When the outlines had been redrawn in this way, the volume and mean radiographic density of the lung slice were calculated, an arbitrary region of interest subroutine being used. Radiographic densities were then converted to physical densities, on the assumption of a linear relationship (justified previously ${ }^{1}$ ), and tissue weight was calculated by multiplying lung slice volume by lung slice density. Tissue volume was derived from tissue weight, on the assumption that air free lung tissue has a specific gravity of 1.04 . The reproducibility of this technique was checked by applying it on 10 occasions to one

Table 2 Details and lung function of 12 patients with fibrosing alveolitis

\begin{tabular}{|c|c|c|c|c|c|c|c|c|c|}
\hline \multirow{2}{*}{$\begin{array}{l}\text { Subject } \\
\text { No (sex) }\end{array}$} & \multirow{2}{*}{$\begin{array}{l}\text { Age } \\
(y)\end{array}$} & \multirow{2}{*}{$\begin{array}{l}\text { Height } \\
(\mathrm{cm})\end{array}$} & \multicolumn{6}{|c|}{ Lung function ( $\%$ predicted) } & \multirow{2}{*}{$\begin{array}{l}\text { Duration of } \\
\text { symptoms (months) }\end{array}$} \\
\hline & & & $F E V_{1}$ & $F V C$ & $T L C$ & $\boldsymbol{R} V$ & $T L C O$ & $\mathrm{KCO}$ & \\
\hline $\begin{aligned} 1 & (\mathrm{~F}) \\
2 & (\mathrm{M}) \\
3 & (\mathrm{~F}) \\
4 & (\mathrm{M}) \\
5 & (\mathrm{~F}) \\
6 & (\mathrm{M}) \\
7 & (\mathrm{M}) \\
8 & (\mathrm{~F}) \\
9 & (\mathrm{M}) \\
10 & (\mathrm{M}) \\
11 & (\mathrm{M}) \\
12 & (\mathrm{M}) \\
\mathrm{Mean} & \\
\text { SD } & \end{aligned}$ & $\begin{array}{l}21 \\
35 \\
39 \\
45 \\
52 \\
52 \\
59 \\
62 \\
63 \\
65 \\
66 \\
69 \\
52 \\
15\end{array}$ & $\begin{array}{r}161 \\
178 \\
166 \\
170 \\
150 \\
180 \\
183 \\
175 \\
165 \\
171 \\
178 \\
176 \\
171 \\
9\end{array}$ & $\begin{array}{l}66 \\
49 \\
70 \\
57 \\
73 \\
71 \\
58 \\
77 \\
77 \\
23 \\
85 \\
88 \\
66 \\
17\end{array}$ & $\begin{array}{l}60 \\
48 \\
67 \\
63 \\
75 \\
77 \\
45 \\
62 \\
63 \\
76 \\
77 \\
64 \\
65 \\
11\end{array}$ & $\begin{array}{l}56 \\
35 \\
64 \\
69 \\
66 \\
75 \\
30 \\
61 \\
58 \\
64 \\
63 \\
55 \\
58 \\
13\end{array}$ & $\begin{array}{l}59 \\
45 \\
69 \\
71 \\
57 \\
71 \\
54 \\
66 \\
40 \\
41 \\
42 \\
49 \\
55 \\
12\end{array}$ & $\begin{array}{l}26 \\
31 \\
30 \\
43 \\
56 \\
37 \\
19 \\
35 \\
34 \\
40 \\
31 \\
34 \\
35 \\
9\end{array}$ & $\begin{array}{l}31 \\
84 \\
52 \\
79 \\
97 \\
59 \\
48 \\
72 \\
73 \\
74 \\
54 \\
69 \\
66 \\
18\end{array}$ & $\begin{array}{r}17 \\
12 \\
24 \\
20 \\
23 \\
36 \\
32 \\
19 \\
40 \\
33 \\
40 \\
27 \\
27 \\
9\end{array}$ \\
\hline
\end{tabular}

FVC—forced vital capacity; TLC—-total lung capacity; RV—residual volume; TLCo-transfer factor; Kco—transfer coefficient. 
SLC ct

(I)

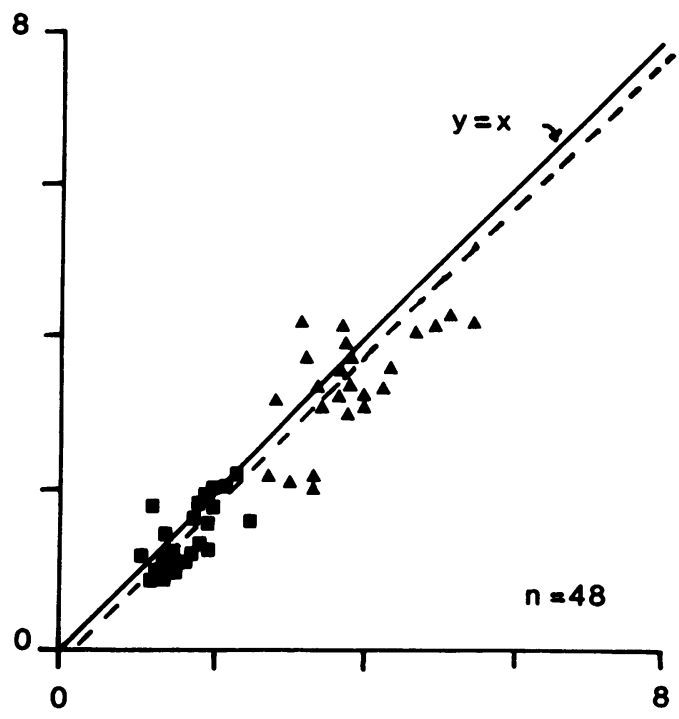

SLC pred (I)

Fig 1 Comparison of computed tomography and whole body plethysmographic estimates of single lung capacity (SLC) in 12 subjects with fibrosing alveolitis (squares) and in 12 with chronic airflow limitation (triangles). SLC predicted represents $47.5 \%$ of the plethysmographic measure of total lung capacity apportioned to the left lung and the remainder to the right lung. ${ }^{8}$ The mean (SD) error in $S L C c t$ was 370 (381) $\mathrm{ml}$. The dashed line represents the SLCct corrected for the known reduction in SLC in the supine posture. ${ }^{7}$

slice of a lung with chronic airflow limitation and on 10 occasions to one slice of fibrotic lung. The measurements of lung slice volume and lung slice weight were reproduced within $\pm 0.5 \%$ on each occasion.

Values for each slice were summed to obtain the total gas capacity, residual volume, and tissue content of each right or left lung. Predictions of the tissue contents of the lungs were derived from the patient's age, sex, and height (which predict total lung capacity - that is, gas alone) by multiplying by 0.114 ; this is taken from Weibel's morphometric study, ${ }^{45}$ for reasons stated in our previous paper ${ }^{1}$ that are discussed in more detail later. Predictions of gaseous lung volumes were taken from Cotes $^{6}$ and modified by recent findings on 165 healthy individuals aged $30-58$ years in this laboratory (which raise predictions of total lung capacity by $5 \%$ and of forced expired volume and forced vital capacity by $10 \%$, and reduce predicted carbon monoxide transfer factor (TLCO) by $7 \%{ }^{7}$ ).

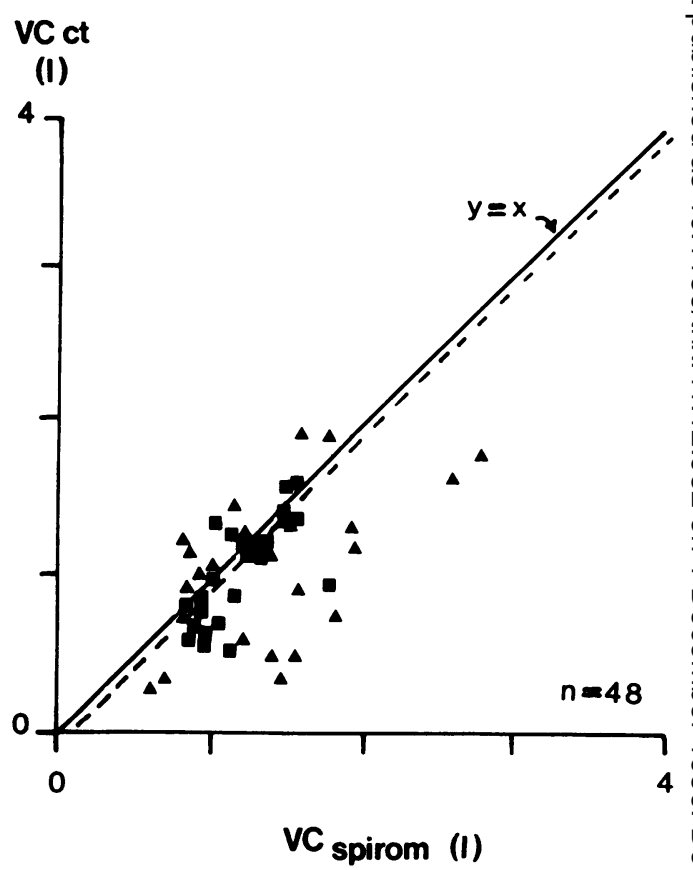

Fig 2 Comparison of computed tomography and spirometri estimates of single lung vital capacity $(V C)$ in 12 subjects with fibrosing alveolitis (squares) and 12 with chronic airflowD limitation (triangles). In each case $47.5 \%$ of the spirometric measurement of whole lung vital capacity was apportioned to $\overline{ }$ the left lung and the remainder to the right lung. ${ }^{8}$ The mean (SD) error in VCct was 257 (406) $\mathrm{ml}$. The dashed line represents the $S L C$ ct corrected for the known reduction in $V C$ in the supine posture.

\section{Results}

Computed tomography based estimates of the vitas capacity and total capacity of each right or left lung are compared with the spirometric and plethyso mographic estimates in figures 1 and 2 , on the assumption that $52.5 \%$ of the volumes derived frono two lungs can be attributed to the right lung. ${ }^{8}$ The mean (SD) computed tomography based estimate on the individual total lung capacities (gas) was 370 (381 $\mathrm{ml}(\mathrm{n}=48)$ smaller than the plethysmographic esti mate (fig 1). The systematic difference of $370 \mathrm{ml}$ is partly due to the reduction in single lung capacity oक about $250 \mathrm{ml}$ that occurs in the supine posture. ${ }^{9}$

The mean (SD) computed tomography based estio mate of the vital capacities of individual lungs wa $257(406) \mathrm{ml}(\mathrm{n}=48)$ smaller than the spirometrif measurements (fig 2). This average difference of 259 $\mathrm{ml}$ is some $100 \mathrm{ml}$ greater than the fall in single lung vital capacity seen when healthy people or patients 
VT ct

(ml)

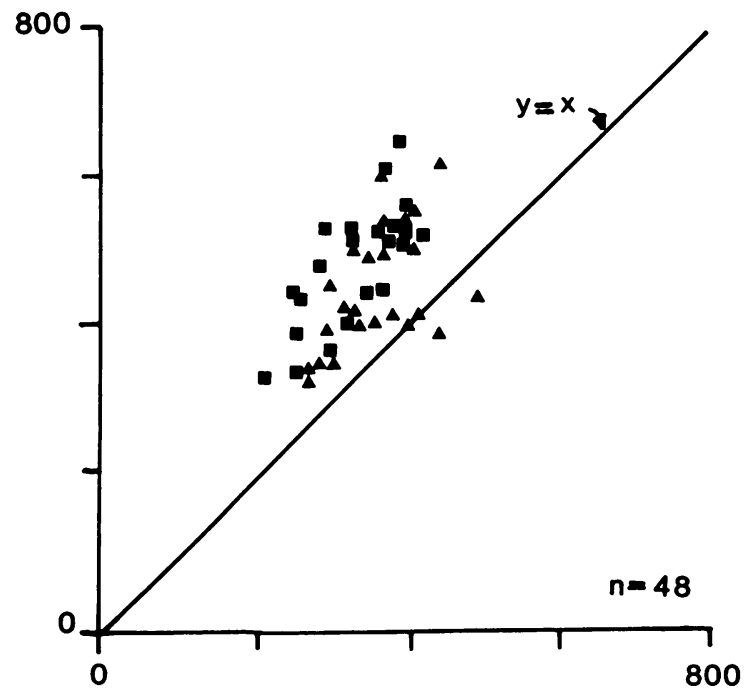

\section{$V_{T}$ pred $(\mathbf{m l})$}

Fig 3 Comparison of computed tomography based estimates (VTct) and predictions of single lung tissue volume based on predicted $T L C^{6}$ in 12 subjects with fibrosing alveolitis (squares) and in 12 with chronic airflow limitation (triangles). In each case $47.5 \%$ of the total lung capacity was apportioned to the left lung and the remaider to the right. ${ }^{8}$ These volumes were then multiplied by Weibel's estimate of lung density at TLC (0.114: ref 4) to obtain the plethysmographic prediction of single lung tissue volume (VT pred). The mean (SD) increased in VTct over predicted values was 139 (52) ml for subjects with fibrosis and 92 (72) $\mathrm{ml}$ for subjects with chronic airflow limitation.

with restrictive or obstructive lung disease lie down. ${ }^{910}$

We presume that before the patients acquired their disease they would have had total lung capacities (gas) that would on average correspond to those predicted from their age, sex, and height. Our best estimate of the tissue content that their lungs would have contained in the absence of disease is the predicted total lung capacity multiplied by the factor of 0.114 that we derived from Weibel's data (see below). Comparison of the computed tomography based estimates of tissue content with such predictions suggested that the individual lungs of the patients with chronic airflow limitation contained 92 (SD 72) $\mathrm{ml}(\mathrm{n}=24)$ of excess tissue. This is equivalent to a mean increase of $26 \%(21 \%)$. Computed tomography estimates of the tissue content in individual fibrotic lungs suggested an excess tissue content of $139(52) \mathrm{ml}(\mathrm{n}=24)$, equivalent to an increase of $43 \%$ (14\%) (fig 3).

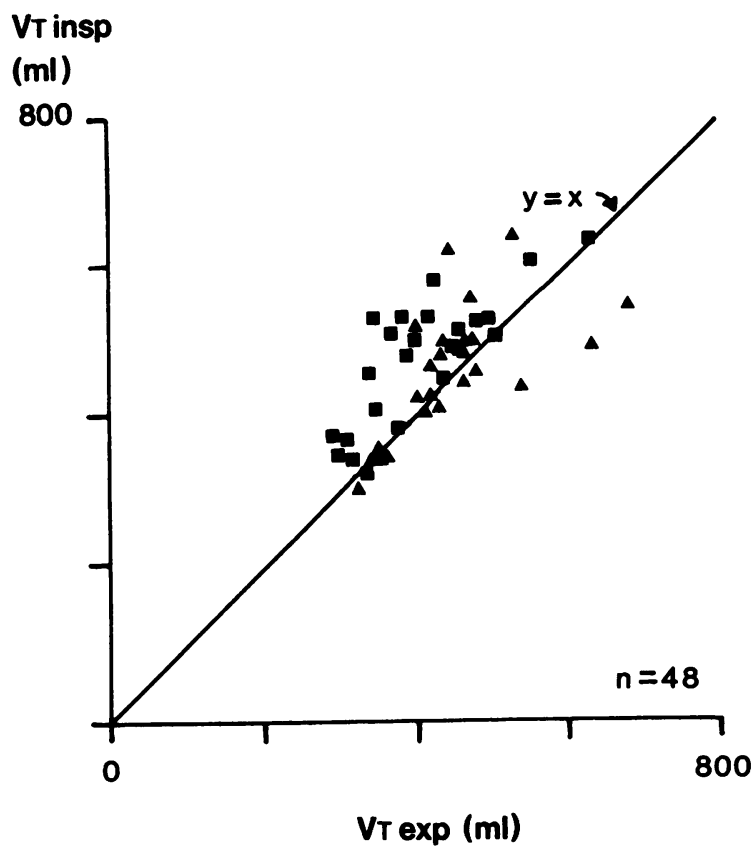

Fig 4 A comparison of single lung tissue volume at total lung capacity (VT insp) and at residual volume (VTexp) in 12 subjects with fibrosing alveolitis (squares) and in 12 with chronic airflow limitation (triangles). The mean (SD) error in VTinsp was 38 (51) $\mathrm{ml}$.

There was good agreement between the tissue contents of each lung at total lung capacity and residual volume (fig 4). The volume at full inspiration exceeded that on full expiration by an average of 38 (51) $\mathrm{ml}$, which is equivalent to an increase of $9 \%$ $(14 \%)$. This conservation of tissue volume allowed us to match inspiratory and expiratory scans and so calculate regional vital capacities. To do this we had to match each actual inspiratory scan with a theoretical expiratory scan whose properties were predicted from the characteristics of the neighbouring pair of actual expiratory scans. This interpolative procedure can be applied only when slice volumes and tissue contents are distributed in a mathematically continuous rather than an erratic fashion. To check that this assumption was valid in diseased lungs with obvious regional variations in structure, we compared the characteristics of each slice with those predicted by interpolation from the properties of its actual neighbours. These comparisons are shown in figures 5 and 6 , which indicate that there are no abrupt changes in lung properties on this scale of sampling (10-15 mm intervals). There is very good interpolation of slice area and therefore volume. There is also good interpolation of lung density and therefore tissue content in the mid $95 \%$ of the lung; but considerable errors 


\section{Inter- \\ polated \\ area $\mathbf{c m}^{2}$}

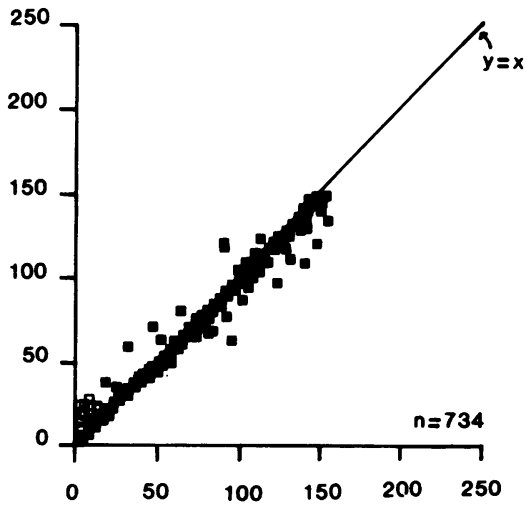

Actual area $\left(\mathrm{cm}^{2}\right)$

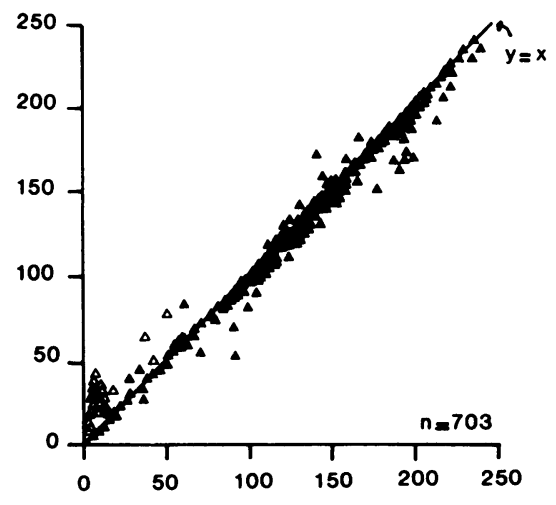

Actual area $\left(\mathrm{cm}^{2}\right)$

Fig 5 A comparison of actual and interpolated estimates of the area of computed tomography slices of single lungs in (left hand panel) 12 subjects with fibrosing alveolitis (squares) and in (right hand panel) 12 subjects with chronic airflow limitation (triangles). In practice, departures from the line of identity will on average be four times less than those shown here. Open squares and open triangles indicate slices, of very small volume, at the extreme apex or base of the lung. Closed squares and triangles indicate slices in the mid $95 \%$ of the lung.
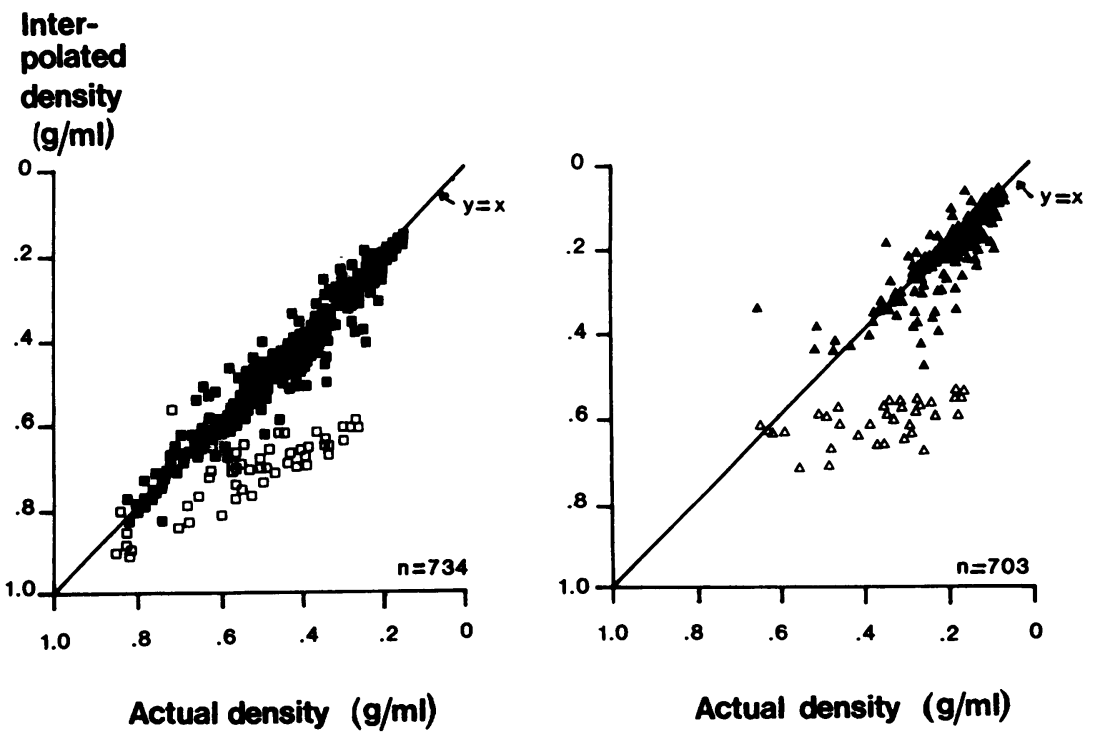

Fig 6 Comparison of actual and interpolated estimates of the density of computed tomography slices of single lungs (left) in 12 subjects with fibrosing alveolotis (squares) and (right) in 12 subjects with chronic airflow limitation (triangles). In practice, the departure from the line of identity will on average be four times less than those shown here. Open squares and open triangles indicate slices, of very small volume, at the extreme apex or base of the lung. Closed squares and triangles indicate slices in the mid $95 \%$ of the lung. 
Table 3 Residual volume to total lung (gas) volume ratios (as percentages) for 12 patients with fibrosis and 12 with chronic airflow limitation

\begin{tabular}{|c|c|c|c|c|c|}
\hline \multicolumn{3}{|l|}{ Fibrosis } & \multicolumn{3}{|c|}{ Chronic airflow limitation } \\
\hline Subject No & Mean & $S D$ (within subjects) & Subject No & Mean & $S D$ (within subjects) \\
\hline $\begin{array}{r}1 \\
2 \\
3 \\
4 \\
5 \\
6 \\
7 \\
8 \\
9 \\
10 \\
11 \\
12\end{array}$ & $\begin{array}{l}23 \cdot 7 \\
22 \cdot 5 \\
32 \cdot 1 \\
34 \cdot 1 \\
26 \cdot 9 \\
30 \cdot 9 \\
29 \cdot 4 \\
54 \cdot 9 \\
42 \cdot 0 \\
32 \cdot 9 \\
28 \cdot 8 \\
22 \cdot 5\end{array}$ & $\begin{array}{l}5 \cdot 3 \\
4 \cdot 5 \\
6 \cdot 1 \\
9 \cdot 2 \\
5 \cdot 2 \\
6 \cdot 9 \\
4 \cdot 0 \\
8 \cdot 3 \\
6 \cdot 1 \\
8 \cdot 6 \\
6 \cdot 9 \\
3 \cdot 5\end{array}$ & $\begin{array}{r}1 \\
2 \\
3 \\
4 \\
5 \\
6 \\
7 \\
8 \\
9 \\
10 \\
11 \\
12\end{array}$ & $\begin{array}{l}59 \cdot 9 \\
48 \cdot 0 \\
65 \cdot 1 \\
84 \cdot 2 \\
70 \cdot 5 \\
66 \cdot 2 \\
83 \cdot 2 \\
55 \cdot 7 \\
53 \cdot 8 \\
57 \cdot 8 \\
54 \cdot 3 \\
87 \cdot 3\end{array}$ & $\begin{array}{r}17.3 \\
12.3 \\
10.7 \\
7.8 \\
12.6 \\
11.1 \\
11.4 \\
12.3 \\
8.9 \\
11.1 \\
19.5 \\
7.4\end{array}$ \\
\hline $\begin{array}{l}\text { Mean } \\
\text { SD }\end{array}$ & $\begin{array}{r}31 \cdot 7 \\
9 \cdot 2\end{array}$ & $6 \cdot 2$ & & $\begin{array}{l}65 \cdot 5 \\
13 \cdot 2\end{array}$ & $11 \cdot 9$ \\
\hline
\end{tabular}

Table 4 Tissue volume to total lung volume (gas and tissue) ratios (as percentages) for 12 patients with fibrosis and 12 with chronic airflow limitation

\begin{tabular}{|c|c|c|c|c|c|}
\hline \multicolumn{3}{|l|}{ Fibrosis } & \multicolumn{3}{|c|}{ Chronic airflow limitation } \\
\hline Subject No & Mean & $\overline{S D \text { (within subjects) }}$ & Subject No & Mean & $S D$ (within subjects) \\
\hline $\begin{array}{r}1 \\
2 \\
3 \\
4 \\
5 \\
6 \\
7 \\
8 \\
9 \\
10 \\
11 \\
12\end{array}$ & $\begin{array}{l}24.4 \\
23.9 \\
21.9 \\
28 \cdot 7 \\
22.8 \\
23.9 \\
21.8 \\
28.0 \\
24.6 \\
32.9 \\
25.6 \\
25.3\end{array}$ & $\begin{array}{r}9.6 \\
9.6 \\
6.1 \\
11.4 \\
7.0 \\
7.6 \\
5.8 \\
7.2 \\
6.8 \\
7.7 \\
12.0 \\
4.1\end{array}$ & $\begin{array}{r}1 \\
2 \\
3 \\
4 \\
5 \\
6 \\
7 \\
8 \\
9 \\
10 \\
11 \\
12\end{array}$ & $\begin{array}{r}9.4 \\
12.5 \\
12.9 \\
10.6 \\
7.9 \\
11.5 \\
9.3 \\
10.2 \\
10.2 \\
8.4 \\
8.4 \\
14.1\end{array}$ & $\begin{array}{l}6.0 \\
5.5 \\
7.5 \\
2.4 \\
3 \cdot 2 \\
2.2 \\
1.7 \\
2.4 \\
4.4 \\
2.1 \\
4.5 \\
4.8\end{array}$ \\
\hline $\begin{array}{l}\text { Mean } \\
\text { SD }\end{array}$ & $\begin{array}{r}25 \cdot 3 \\
3 \cdot 2\end{array}$ & $7 \cdot 9$ & & $\begin{array}{r}10 \cdot 5 \\
1.2\end{array}$ & 3.9 \\
\hline
\end{tabular}

occur in the small volumes of lung at the extreme apices and costophrenic margins, where partial volume artefacts are greatest.

In the lungs of healthy supine men the residual volume to total gas volume ratio of each scan slice of lung averaged $23 \%$ (SD $5 \%$ ). ${ }^{1}$ In the patients they were higher and more variable, averaging $32 \%(9 \%)$ in the patients with fibrosis and $66 \%(13 \%)$ in those with chronic airflow limitation in the mid $70 \%$ of lung volume (table 3 ). In healthy subjects the distribution of tissue volume is very uniform at about $12 \%(2 \%)$ of total lung volume in the mid $70 \%$ of total lung volume. ${ }^{1}$ In the patients with fibrosis the tissue volume was higher, averaging $25 \%(3 \%)$ of total volume, and in patients with chronic airflow limitation the corresponding average was $11 \%(1 \%)$ (table 4$)$.

\section{Discussion}

Several features of these results suggest that the computed tomography techniques for determining regional gas and tissue volumes can be applied to diseased lungs. These are the agreement between computed tomography based and whole body plethysmographic estimates of total lung capacity; the agreement between computed tomography based and spirometric estimates of vital capacity; the agreement between inspiratory and expiratory tissue contents; and the agreement between actual and interpolated values of area and slice density.

The finding of apparent increases in lung tissue content in both conditions rests on the accuracy of our predictions of normal values. The figure we used comes from a morphometric study by Weibel, ${ }^{45}$ and is the only one we know that allows us to distinguish and subtract the weight of the main bronchi and all blood vessels greater than $5 \mathrm{~mm}$ in diameter, which are automatically excluded from computed tomography estimates of lung weight by boundary selection. The figure did also provide a good prediction of com- 
puted tomography estimates of normal lung weight, the computed tomography estimate exceeding the predicted value by an average of 31 (SD 70) $\mathrm{ml}$, equivalent to an excess of $6 \%(18 \%) .{ }^{1}$ There is also agreement with independent estimates of lung weight by Pierce et $a l^{11}$ and Armstrong et al, ${ }^{12}$ who used the difference between radiographic and gas dilution lung volumes as a measure of tissue volume. In these studies mean lung weight was estimated to 720 (SD 37) and $843(110) \mathrm{g}$ respectively. In both cases the estimates were made in the upright position, at total lung capacity and functional residual capacity respectively. Rhodes et al, ${ }^{13}$ using positron emission tomography,

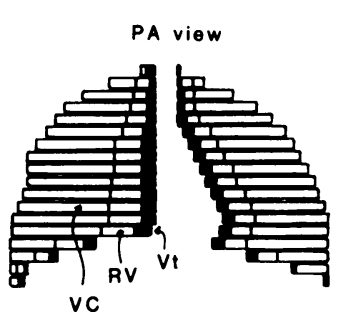

v C
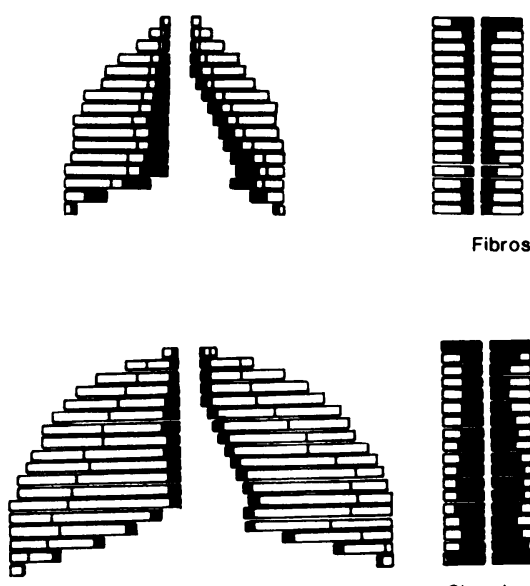

Chronic airflow limitation

Fig 7 Graphical presentation of regional information obtained from computed tomographs at total lung capacity and residual volume in one healthy man (top) one subject with fibrosing alveolitis (centre), and one subject with chronic airflow limitation (bottom). Each slice represents an equal percentage of the total height of the lung. The diagram on the left shows for each slice of lung, local tissue volume $(V \mathrm{~T})$, indicated by the shaded bar; residual volume $(R V)$, indicated by the smaller unshaded bar; total gas volume (TGV) given by the combined length of the two unshaded bars: and total lung volume $(T L V)$ given by the combined length of all three bars. These characteristics are shown, as proportions of total gaseous volume (TGV) or total volume (gas and tissue, $T L V$ ) in the sets of bar charts on the right. measured lung density during quiet breathing, close $\frac{\sqrt{9}}{0}$ to functional residual capacity. They found it to be $0.29(0.08) \mathrm{g} / \mathrm{ml}$ (including the vascular component) $\frac{\overline{\bar{N}}}{\overline{0}}$ and $0 \cdot 12-0 \cdot 16 \mathrm{~g} / \mathrm{ml}$ for extravascular lung density. In $\vec{\Phi}$ a 6 litre lung this would give lung weights of 870 and 2 $470 \mathrm{ml}$ respectively.

The finding of an apparent increase of $43 \%$ (SD $\vec{\circ}$ $14 \%)$ in the tissue content of fibrotic lungs accords $\vec{\overrightarrow{ }}$ well with other evidence on the characteristics of $\vec{\sim}$ fibrosing alveolitis. ${ }^{14-17}$ In the reviews cited there $\vec{F}$ was a constant finding of increased material of a cellu- $x$ lar, fibrotic, or mixed nature. Our previous study sug.. gested that computed tomography could determine $\vec{N}$ changes in lung tissue content of the order of $\pm 5 \mathrm{ml}, \underset{\omega}{\stackrel{\omega}{~}}$ which is about $1 / 28$ th of the average volume of excess $\mathrm{N}$ material found in fibrotic lungs. This suggests that 을 some computed tomography measure of tissue con- $-\overrightarrow{ }$ tent might be of value in assessing the severity, $\mathbb{D}$ progress, or response to treatment of the disease.

The finding of a smaller but substantial increase- 3 of $26 \%$ (SD $21 \%$ ) -in the tissue content of lungs with $\stackrel{\Phi}{-}$ chronic airflow limitation was not expected. Fletcher $\vec{\bullet}$ et $a l^{18}$ and Burrows et $a l^{19}$ have described radiographic and functional criteria for the diagnosis of emphysema in life, including a grossly elevated increased TLC (greater than $120 \%$ predicted) and a reduced TLCO (less than $52 \%$ and $55 \%$ predicted respectively). Eleven of our 12 subjects with chronic $\frac{\alpha}{\varnothing}$ airflow limitation had a TLC greater than $120 \%$ pre- $\varrho$ dicted and one had a TLC of $114 \%$ predicted. In 11 of $\overrightarrow{\overrightarrow{0}}$ the 12 the TLCO was less than $55 \%$ predicted. The computed tomography appearances in each case were? those of emphysema. ${ }^{20}$ On this basis we believe that all the subjects had emphysema. The image we had of this condition was of a lung made lightweight and overblown by the destruction of alveoli. In these lungs. the density was low because of distension $\left(0 \cdot 114 \frac{O}{3}\right.$. $0.026) \mathrm{g} / \mathrm{ml}$, compared with $0.126(0.017) \mathrm{g} / \mathrm{ml}$ in healthy men), but the total tissue content was raised. This excess material could be inflammatory as all the subjects had a long smoking history and coincident? chronic bronchitis. ${ }^{3}$ The only reference we have been able to find on the tissue content of emphysematous. lung supports the idea that it is not associated with ao loss of lung weight. ${ }^{21}$

The technique described here enables areas of raised or diminished tissue content or air trapping to be quantified on a firmer basis than previously from computed tomography scans, and is complementarye to the statistical approach described by Hayhurst $e$ e $a^{22}$ It provides quantitative measurements of regional function that might help in the preoperative assessment of patients due to have total or partia他 lung resection. For this purpose we need to presen the information in a way that can be appreciated easily, and we have chosen the solution illustrated ine 
figure 7, which compares the findings in a normal subject with the findings in one of the patients with fibrosing alveolitis and one of the patients with chronic airflow limitation. In principle, the graphical display can be superimposed on a conventional posteroanterior chest film. It is, however, essential to note that the graph is constructed from data obtained in a supine patient whereas most posteroanterior views are taken with the patient standing or sitting up.

We suggest that the data reported here support the use of computed tomography to study regional function in the diseased lung.

We would like to thank the physicians of the Brompton Hospital who allowed us to study their patients and in particular Professor Margaret TurnerWarwick. We also thank Wendy Jordan and Nancy Arbutt for their help in the performance and organisation of the computed tomography and Cathy Evans for her expert secretarial assistance.

\section{References}

1 Denison DM, Morgan MDL, Millar AB. Estimation of regional gas and tissue volumes of the lung in supine man using computed tomography. Thorax 1986;41:620-8.

2 Morgan MDL, Denison DM, Strickland B. Value of computed tomography for selecting patients with bullous lung disease for surgery. Thorax 1986;41:855-62.

3 Medical Research Council. Definition and classification of chronic bronchitis for clinical and epidemiological purposes. Lancet 1965;ii:755.

4 Weibel ER. Morphometry of the human lung. Berlin: Springer-Verlag, 1963.

5 Weibel ER. The pathway for oxygen. Cambridge, Massachusetts: Harvard University Press, 1984:281-9.

6 Cotes JE. Lung function: principles and application in medicine. 3rd ed. Oxford: Blackwell Scientific Publications, 1975

7 Al-Hillawi AHS. The role of exercise tests in the detection and management of lung disease. MD thesis, University of London, 1986.

8 Pierce RJ, Brown DJ, Denison DM. Radiographic, scintigraphic and gas-dilution estimates of individual lung and lobar volumes in man. Thorax 1980;35:777-80.

9 Svanberg L. Influence of posture on the lung volumes, ventilation and circulation in normals; a spirometricbronchospirometric investigation. Scand J Clin Lab Invest 1957;9 (suppl 25):1-195.

10 Allen SJ, Hunt B, Green M. Fall in vital capacity with posture. Br J Dis Chest 1985;79:267-71.

11 Pierce RJ, Brown DJ, Denison DM. Radiographic and gas-dilution estimates of individual lungs and lobar volumes in man. Thorax 1980;35:777-80.

12 Armstrong JD, Gluck EH, Crapo RO, Jones HA, Hughes JMB. Long tissue volumes estimated by simultaneous radiographic and helium dilution methods. Thorax 1982;37:676-9.

13 Rhodes CG, Wollmer P, Fazio F, Jones T. Quantitative measurements of regional extravascular lung density using positron emission tomography. $J$ Comput Assist Tomogr 1981;5:783-91.

14 Crystal RG, Fulmer JD, Roberts WC, Moss ML, Line BR, Reynolds HY. Idiopathic pulmonary fibrosis: clinical, histologic, radiologic, physiologic, scintigraphic, cytological and biochemical aspects. Ann Intern Med 1976;85:769-88.

15 Fulmer JD, Roberts WC, Von Gal EK, Crystal RG. Morphologic - physiologic correlates of the severity of fibrosis and degree of cellularity in idiopathic pulmonary fibrosis. J Clin Invest 1979;63:665-76.

16 Turner-Warwick M, Burrows B, Johnson A. Cryptogenic fibrosing alveolitis: clinical features and their influence on survival. Thorax 1980;35:171-80.

17 Wright PH, Buxton-Thomas M, Kreel L, Steel SJ. Cryptogenic fibrosing alveolitis: pattern of disease in the lung. Thorax 1984;39:857-61.

18 Fletcher CM, Hugh-Jones P, McNichol MW, Pride NB. The diagnosis of pulmonary emphysema in the presence of chronic bronchitis. $Q J$ Med 1963;32:33-49.

19 Burrows B, Niden AH, Fletcher CM, Jones NL. Clinical types of chronic obstructive lung disease in London and in Chicago. Am Rev Respir Dis 1964;90:14-27.

20 Goddard PR, Nicholson EM, Laszlo G, Watt I. Computed tomography in pulmonary emphysema. Clin Radiol 1982;33:379-87.

21 Pierce JA, Hocott JB, Ebert RV. The collagen and elastin content of the lung in emphysema. Ann Intern Med 1961;25:210-22.

22 Hayhurst MD, MacNee W, Flenley DC, et al. Diagnosis of pulmonary emphysema by computed tomography. Lancet 1984;ii:329-32. 